\title{
THE SELF-CONCEPT IN CONSUMER BEHAVIOUR BASED ON THE EXAMPLE OF LUXURY BRANDS
}

\author{
Christopher B. Jakob ${ }^{1}$ \\ ${ }^{1}$ UCAM Universidad Católica San Antonio de Murcia in Spain, christopher.b.jakob@gmail.com
}

\begin{abstract}
The human beings' image of himself has been researched for decades. It influences every person individually every day and is therefore tremendously important for the consumer behaviour. The selfconcept in consumer behaviour reflects more types of self-perspectives where the actual and the ideal self-image as well as the social self-image and the ideal social self-image belong to. The actual selfconcept represents the current perceived state of the person and it reflects his current image of himself. The ideal self-concept is a formation of the future potential self-concept as it constitutes the achievement of the desired image of a person. The social self-concept represents the image the individual thinks others might attach to him. According to the Self-Congruity Theory individuals possess a need to express their self-identity.

Three types of motivation exist to aspire to congruency. The first one is the individual's basic need to pursue or to increase a positive self-esteem. The customer's aspiration for consistency represents the second type of motivation. The third motivation is the ambition of self-assessment. The results indicate that human beings are able to satisfy these three motivations due to the purchasing and possessing of luxury brands. Additionally it shows that people are in the position to enhance their self-esteem and to achieve their desired ideal-self because of the buying of luxury brands.
\end{abstract}

\section{Keywords}

Self-expression; self-concept; luxury brand; consumer behavior.

\section{JEL Classification}

D11, D21, D47

DOI: https://doi.org/10.14311/bit.2020.03.05

Editorial information: journal Business \& IT, ISSN 2570-7434, CreativeCommons license (c) (i) published by CTU in Prague, 2020, http://bit.fsv.cvut.cz/ 


\section{Introduction}

Over hundreds of years luxury brands and products have held a fascination for human beings (Cristini, Kauppinen-Räisänen, Barthod-Prothade, \& Woodside, 2017). Nearly every commodity item is also available as an extraordinary, classy, exclusive model. What are the reasons for this kind of fascination? (Loureiro, Maximiano, \& Panchapakesan, 2018) The functional value plays a minor role with reference to luxury brands. As a result of this the consumption of luxury brands seems to be irrational (Seo \& Buchanan-Oliver, 2019). Due to the increased wealth of the industrial nations in the eighties and nineties even customers who did not belong to the upper-class were able to buy luxury brands. Democratisation of luxury is the term for this transformation. As a result more and more people buy luxury brands (Atwal \& Williams, 2009). Even in times of financial crisis people do not stop consuming luxury brands (Roncha \& Montecchi, 2017). What are the reasons that customers are willing to pay more than 500,000 EUR for a sportscar or a limousine whereas they have the opportunity to buy a much cheaper car which enables them to be mobile too? (Kapferer \& Valette-Florence, 2016b) Another example is that consumers buy watches that cost thousands of euros, although they could buy much cheaper watches which also fulfil the function to indicate the correct time (Semaan, Ashill, Williams, \& Dhabi, 2019). This deductive study refers to the Self-Expression Model to give answers to the question why people are willing to spend an enormous amount of money on the consumption of luxury brands.

\section{Theoretical framework}

\subsection{Luxury brands}

The literature does not offer an established definition of the term luxury brand (Kapferer \& ValetteFlorence, 2016a). Despite different existing definitions researchers are of the opinion that consumers decide whether the brand is assessed as a luxury brand (Kapferer \& Michaut, 2015). There are five characteristics that define a luxury brand (Ko, Costello, \& Taylor, 2017). The first criterion is a high quality of the manufacture and the material used (Kapferer \& Laurent, 2016).

The second factor is the offer of emotional benefits due to an authentic value (J. Kim \& Joung, 2016).

To build an eminent image based on a high quality of service, craftsmanship and artisanship represents the third element (Miller \& Mills, 2012).

The fourth criterion is the dignity to edict a superior price.

The fifth characteristic is a profound relationship respectively a deep resonance with the consumer (Fastoso, Bartikowski, \& Wang, 2018).

\subsection{Self-Expression Model}

The human being's self-concept has a major significance for the research of the customer behaviour as a result of the fact that his image of himself influences his behaviour (Gecas, 1982). The self-concept is defined as all cognitively represented feelings and thoughts of a human being with reference to himself (Sirgy, 1982). People perceive themselves as a specific personality (Uher, 2017).

The personality of a person is strongly connected with his self-concept (Adam, Obodaru, Lu, Maddux, \& Galinsky, 2018). Important elements of the individual's self-concept are personality traits which are distinguishable characteristics of an individual's personality (Pilarska, 2018). All human-being's mind anchored personality traits due to its subordinate dimension are defined as personality (Mõttus, 2016). The self-concept refers to individual personality traits (Geukes, van Zalk, \& Back, 2018). The individual's self is understood as a process of dialogue. They differentiate between the person as an object "Me" and the person as an subject "I" (Porankiewicz-Żukowska, 2017). Similar to objects or human beings the "Me" could be part of reflexive perception and assessment. The "Me" is the entirety of the self- 
centered knowledge. The "I" is understood as a judging thinking that responds to different conditions by virtue of perceptions, learning and experiences (Mead, 1913). For this reason the "I" is not able to be a direct object of the mental activity (James, Burkhardt, Bowers, \& Skrupskelis, 1890). The system of intentions, values, rules and attitudes build the knowledge about the individual's self (Gecas, 1982). As a result of this human beings can coordinate their actions perceptions, feelings and emotions in relation to their environment with particular regard of their family, friends and reference groups (Jia, Soucie, Alisat, Curtin, \& Pratt, 2017). Due to these information human beings are able to find out who they are. The self-concept is the result of the individual's assessment about himself (Fox, Bacile, Nakhata, \& Weible, 2018). The self-concept has a dynamic and complex cognitive structure and is defined as the individual's knowledge about himself and the individual's point of view about the own personality (Marsh et al., 2019). Exogenous and situational influences affect the customer's behaviour that is based on his personality traits (Pappas, Kourouthanassis, Giannakos, \& Chrissikopoulos, 2017). The self-concept is a unique and active process of social experiences (Schwartz, Meca, \& Petrova, 2017). Researchers showed that varied human being's self-concepts are multidimensionality (Feng, Yan, Huang, Han, \& Ma, 2018). Literature differentiates between actual and potential self-concepts (Sirgy, 1982). The factual self-concept which is also known as the actual self-concept is the current perceived state of the person and it reflects his current image of himself (Astakhova, Swimberghe, \& Wooldridge, 2017). Particular characteristics like attitudes and physical characteristics like the hair colour and the height as well as the social identity like nationality or group memberships represent the individual's actual self-concept (Barnett \& Womack, 2015). The potential self-concept is a specific self the individual could achieve in the future (Mishra, 2016). The potential future self-concept works as an incentive with regard to the individual's future behaviour due to the development of desirable and avoidable images (Ein-Gar, 2015). Due to the potential self-concept the actual self-concept gets an interpretative and assessable context. The ideal self-concept is a formation of the future potential self-concept as it represents the attainment of the desired image of a person (Tsai, Chang, \& Ho, 2015). The ideal selfconcept refers as a reference point which the individual compares with his actual self-concept (Sampthirao, 2016). Due to the self-esteem motive people try to achieve their ideal self-concept if they identify a gap after the comparison between the actual self-concept and the ideal self-concept (Japutra, Ekinci, Simkin, \& Nguyen, 2018). Values of society are able to influence the stable construct of the desired ideal self-concept (Mandel, Rucker, Levav, \& Galinsky, 2017). Another dimension of the selfconcept is the social self-concept that represents the image the individual thinks others might attach to him (Sirgy, 1982). At the same time only one type of composition of the self could be active but the individual's self-concept contains various multiple self-concepts with several functions (TurnerZwinkels, Postmes, \& van Zomeren, 2015).

The working self-concept proposes that the self-concept is malleable, dynamic and changing in response to different situations (Showers, Ditzfeld, \& Zeigler-Hill, 2015). The working self-concept includes peripheral as well as central self-concepts. The peripheral self-concepts will be activated if social situations change (Berkman, Livingston, \& Kahn, 2017). The central self-concept are resistant to changes and they are understood as the core of the working self-concept (Markus \& Wurf, 1987). Only the activated self-concepts influence the individual's behaviour and therefore it is a changeable and a variable construct. The human beings' motivational status and the situational aspects build the basis for the different activated self-concepts (Brenner, Serpe, \& Stryker, 2018). The Self-Congruity Theory explains that individuals possess a need to express their self-identity (Sirgy, 1982).

There exist three types of motivation people aspire to congruency: The first type of motivation is the basic need of human beings to pursue or to increase a positive self-esteem (Sedikides, Gaertner, \& Cai, 2015). The gain of self-esteem might lead to a behaviour which allows the achievement of the individual's ideal self-concept (Sampthirao, 2016). The self-esteem represents the incongruity between the actual and the ideal self (Ümmet, 2015). To be able to measure the distance between the actual 
and the ideal self it is necessary that people have a desirable image of their personality (Mandel et al., 2017). The aspiration for social acceptance comes with the quest of a positive self-esteem (Mahadevan, Gregg, Sedikides, \& Waal-Andrews, 2016). The human beings' behaviour is influenced by his aspiration of a higher level of self-esteem and this enables the attainment of the individual's ideal self-concept (Japutra et al., 2018).

The second type of motivation is the customer's aspiration for consistency (Sutton, 2018). Reliability, predictability and resistance are preferred by human beings (Setyawan \& Kussudiyarsana, 2015). Individuals possess an intrinsic need to support and to confirm their self-identity (Obschonka, Silbereisen, Cantner, \& Goethner, 2015). The social environmental exploratory feedback mechanisms provide the basis for the self-consistency (Richman, Slotter, Gardner, \& DeWall, 2015). People try to achieve authentication granted by a third person as regards of their self-concept (Whelpley \& McDaniel, 2016).

The ambition of self-assessment represents the third type of motivation (Sedikides et al., 2015). The hypothesis of congruency was revised in the past but with reference to the actual and the ideal self it is still valid (Tooray \& Oodith, 2017). The individual's behaviour depends on the various roles which are required by their environment which points out that their self is not stable (Aaker, 1999).

\subsection{Symbolic Interactionism}

The concept of the symbolic interactionism deals with the involvement of the individual in the social context. The focus of this concept is the influence and the shaping of an individual by society and the impact of the interaction of individuals with respect to society (Chang, Wang, Guo, \& Cui, 2018).

The "looking-glass-self" (Sirgy, 1982) is explained as the reflection of the individual's interaction with his environment and it helps the customer to preserve awareness of his self (Gecas \& Schwalbe, 1983). With reference to the looking-glass-self the social behaviour between society and social groups plays a major role (Cast \& Stets, 2016). A successful communication is possible if transmitter and acceptor possess symbols with the same constituted meaning (Carter \& Fuller, 2016). The effect of the specific symbols indicate that human beings behave according to what they are expected to do (Kenny \& Fourie, 2015). It is due to the social interactionism and will become effective because of the interpretative process (Chang et al., 2018). In the context of existing interactions situations and actions occur during an evolving process of interactionism. They are not determined by structural and functional specifications (Fischer \& Wiswede, 2009). People intend to become members of positively evaluated groups because of their intention to achieve a positive social identity and the achievement of selfworth (Martiny \& Rubin, 2016). Human beings try to maintain or to create a positive assessment. Individual's social identity is provided by his membership to a specific group and the group evaluation (M. A. Hogg, Abrams, \& Brewer, 2017). The individual's self-concept is build by self-assessments and different self-characterizations (Suchańska \& Worach, 2017). Self-identification is separated into social and personal identifications. Social identification includes memberships to social categories and is defined as the totality of social identifications (Trepte \& Loy, 2017). Individual's personal identification represents human being's facets of the person's self-concept and the entirety of the personal identification (Chen, Urminsky, \& Bartels, 2016). Depending on the situation people define themselves by their social or their personal identities (Wry \& York, 2017). The individual's membership to selective groups and the individual's identification with social categories influence his behaviour (Zeugner-Roth, Žabkar, \& Diamantopoulos, 2015). The human being's self-esteem is a result of the comparison of the in-group to particular peer groups (Dimofte, Goodstein, \& Brumbaugh, 2015). Individuals have the intention to achieve, keep up and increase a positively evaluated distinction of the in-group in comparison to out-groups (Fielding \& Hornsey, 2016). People are able to satisfy the need for a positive self-esteem if the comparison leads to a positive result for the in-group (Martiny \& Rubin, 2016). The 
relevance of the dimension of comparison and the importance of the comparison group leads to specific groups human beings choose for the comparison (Jetten et al., 2017). The more important the dimension of comparison with respect to the social identity is, the more meaningful is the group comparison with reference to the development of a positive social identity (Haslam, Cornelissen, \& Werner, 2017). The result of comparison is more significant if the out-group possesses a high relevance for the individual. Due to a modification of the comparison parameters people have the possibility to change and to influence the assessment (Mor Barak et al., 2016).

Social mobility is an individualistic strategy to achieve and create a positive distinction and a positive social identity. To become a member of an out-group with a higher level of social status it is necessary to reduce the identification with the in-group (Trepte \& Loy, 2017).

With the help of social creativity human beings are able to modify the dimensions of comparison. Another option is the avoidance of a comparison with an out-group with a higher level of status (Martiny \& Rubin, 2016). A part of the individual's self-concept refers to the membership to particular social groups and the type of relationship among these groups (McGowan, Shiu, \& Hassan, 2017). The pursuit of a positive social identity leads persons try to become members of groups which have a positive assessment (Mittal, 2015). Within the totality of the individual self-concept the representation of the different social identifications represents the social identity and it arises due to the process of categorization (Steffens, Schuh, Haslam, Perez, \& van Dick, 2015).

The self-concept consists of the personal and the social identity and could influence the individual's self-concept in negative or a positive way (Constantine, 2017). Literature differentiates between interpersonal and intergroup behaviour (Gardner \& Garr-Schultz, 2017). The personality identity is based on the interpersonal behaviour whereas the social identity is based on the intergroup behaviour (M. A. Hogg et al., 2017). The self-concept is enormously influenced by the social identity due to the fact that human beings mention group-based characteristics to explain who they are (Vernuccio, Pagani, Barbarossa, \& Pastore, 2015). Individual's characteristics like gender, race or age leads automatically to a specific group membership (M. A. Hogg et al., 2017). The individual's possession of preferred group symbols signalize to the members that this person have the same symbolic values which leads to the member's acceptance (Harrison et al., 2018). Group memberships enable human beings to extend their self-concept and increase their social status (Trepte \& Loy, 2017). Because of repeated interactions between individuals symbolic interactionism shows how society is build (Tran \& Pham, 2016). The concept of a situational self-image represents one example of a concept which is the person's self-concept at a particular point in time (Roe \& Bruwer, 2017). The desired self-image of a person which he tries to communicate to others with respect to attitude, feelings, apperception and the behaviour resulting from this ambition is understood as the situational self-image (Bloch \& Richins, 1992). To communicate their specific image of themselves individuals are willing to adjust their behaviour to achieve this image in the minds of the reference group (Hart, Adams, Burton, \& Tortoriello, 2017). Impression management is meant when people behave in a specific way to receive the desired reaction on behalf of the reference group (Benthaus, Risius, \& Beck, 2016). Specific situations and social stimuli influence the behaviour of human beings. People develop different selfconcepts with different personality traits depending on respective situations (Fox et al., 2018).

\subsection{Symbolic consumer behavior}

The functional relevance of products is less relevant than their symbolic meaning (Grubb \& Grathwohl, 1967). Customers define and develop their self as well as they communicate with the social environment with the possession of products. Products are no longer used to satisfy only the core benefit (Mittal, 2015). To guarantee a symbolic communication without any misunderstandings it is necessary that all involved individuals interpret the symbols in the same way (Grouchy, D'Eleuterio, 
Christiansen, \& Lipson, 2016). Human beings define most of the existing brands and products as symbols because of the medial accumulation of acceptation and the cultural context (Išoraite, 2018). To communicate their current self-image or to minimize the gap between the current and the ideal selfimage human beings use brands (Ross, 1971). According to the theory of self-enhancement human beings are able to maintain or to increase their current self-concept due to the consumption of a brand (Malhotra, 1988). Products and brands are stimuli, which might help individuals to define their selfimage. This perception underlines the impact of the symbolic use of brands and is applicable for human beings with a non-established self-image (Solomon, 1983). Therefore customers are able to express their self with the help of the possession of brands (Aaker, 1999).

\section{The Self-Expression Model related to luxury brands - Conclusion}

The human being's intrinsic pursuit of a positive self-esteem can be achieved by purchasing and possessing a luxury branded product (Roy, 2016). The self-esteem represents the distance between the current self and the ideal self of an individual (Ümmet, 2015). As a result of the positive and desired characteristics of luxury brands customers are in the position to reduce this discrepancy by the possession of a luxury brand. This leads to a high level of self-esteem (Zhu, Teng, Foti, \& Yuan, 2019). Customers can express their desired self-concept due to the fact that the personality of the luxury brand is transferred to the consumer's personality (Shimul, Phau, \& Lwin, 2019). The owner of a luxury brand receives social acceptation by his environment because of this brand (Dogan, Ozkara, \& Dogan, 2018). Due to the possession of this brand the social environment imputes him a high level of social status (Atwal \& Williams, 2009). Prestige shows the social standing of an individual within society and its social status (Seo \& Buchanan-Oliver, 2019). Customers have the opportunity to achieve social status and therewith prestige due to the possession of luxury brands. Brands and especially luxury brands are used and understood as status symbols (Roux, Tafani, \& Vigneron, 2017). The possession of luxury brands shows the customer's financial power as an expression of his wealth (Atwal \& Williams, 2009). The individual who owns such luxury brands receives esteem and tribute by other members of society. As a result of this, luxury brands offer the individual a social value of gratification due to the prestige function (Sung \& Phau, 2019).

People have a desire for consistency and a need for reliability, some consumers buy luxury brands to satisfy these needs (Can \& Erdil, 2018). Their guarantee of high quality and their consistency is the reason why especially luxury brands are able to meet the need for an individual's reliability (Uggla, 2017). Luxury brands enable consumers to express their desired personality and their desired selfconcept as well as the possession of a luxury brand helps to distinguish from others (Ko et al., 2017). The customers need to differentiate from others explains the need for uniqueness. Luxury brands are predestinated to demonstrate the individual's self-concept, as they have a high level of specificity and uniqueness, which normal brands do not possess (Kauppinen-Räisänen, Björk, Lönnström, \& Jauffret, 2018). The function of distinction plays a major role with reference to the reasons why customers purchase luxury brands (J. E. Lee, Hur, \& Watkins, 2018). Consumer have a strong desire for individuality and they are able to satisfy their need for uniqueness by the possession of luxury brands (Shin, Eastman, \& Mothersbaugh, 2017). Customers perceive brands as unique if their possession is reserved for a minority. Only if this assumption is given the individual's intention for uniqueness can be satisfied (Dogan et al., 2018). Luxury brands often reduce their offer to extend their uniqueness value which is preferred by customers who see a benefit in the function of distinction (Moulard, Raggio, \& Folse, 2016). In comparison to ordinary brands luxury brands have a higher level of uniqueness which is due to the excellent product quality, their restricted availability and their high price (Seo \& Buchanan-Oliver, 2019). Therefore they have the possibility to satisfy the individual's need for uniqueness in a better way than ordinary brands (Kauppinen-Räisänen et al., 2018). Consumers who belong to the upper-class 
use luxury brands to demonstrate their social status and to distinguish from human beings who belong to a different social stratum (Sung \& Phau, 2019). Becoming a member of a specific group can be achieved by the possession of symbols which are preferred by this reference group and the membership shows the members that this individual has got the same values. As a result the group will accept the aspirant (Harrison et al., 2018). This leads to the result that the individual's need for social appreciation is fulfilled and negative judging is avoided (Dogan et al., 2018). These mentioned symbols could be luxury brands. Due to the fact that most human beings try to extend their social status which comes along with the membership to an upper-class group, customers are of the opinion to achieve this with the possession of luxury brands (Conejo \& Cunningham, 2016). The prestige function of luxury brands could be used to strengthen the individual's status within a group and to show the membership to this group or it could be used to enhance the individual's status (S. Lee, Baumgartner, \& Winterich, 2018).

Luxury brands satisfy the customer's prestige motive far better than generic brands due to their higher social attentiveness during the buying-process and due to the fact that they are more adequate to demonstrate wealth and social status (Tak, Pareek, \& Rishi, 2017). Because of purchasing and possessing luxury brands consumers receive social attention (Shin et al., 2017). This attention helps to express the individual's symbolic values (Sharda \& Bhat, 2018). Luxury brands hold desirable associations and values which possess social and personal relevance like prestige (Ko et al., 2017). The prestige motive and the conspicuous consumption motive are main reasons why people buy luxury brands (E. Lee, M. Edwards, Youn, \& Yun, 2018).

Chanel, Armani and Versace are examples of luxury brands that have a strong brand personality with a close connection to the personality of the founder of the brand (Dion \& Borraz, 2015). As a result of this the luxury brand is understood as a symbol which comes along with an intrinsic character by transferring the attached personality traits of the brand to the personality of the individual (Shin et al., 2017). People are able to acknowledge and enhance their self-concept because of the consumption of luxury brands (Janssen, Vanhamme, \& Leblanc, 2017). An individual is able to approve his classiness and athleticism by purchasing a luxury sports car, like a Ferrari or Porsche. This explains the meaning of the self-concept, with reference to the individual, that desires to enhance his self-worth and to express his personality (Roux et al., 2017). The private self-concept is related to a process, where the customer tries to transfer the image of the purchased luxury brand to his self and to achieve his desired standard of value because of the acquisition (M. Hogg, Cox, \& Keeling, 2000). The self-gratification is one of the intentions of this behaviour (Krishnamohan \& Suma, 2018). The achievement of selffulfillment and the self-gratification are intrinsic motives which could be achieved without the influence of the surroundings (Kassim \& Zain, 2016). The collective self-concept is meant when the consumer tries to gain external standards, which are demonstrated by the individual's reference groups (M. A. Hogg et al., 2017). Especially luxury brands help the individual to differ from others by showing by means of the possession of a luxury brand that he belongs to a specific group. This luxury brand possession reveals the financial status of the customer (Trepte \& Loy, 2017). The public self-concept relates to the social acceptation of the individual's moral concept, by the social environment (M. Hogg et al., 2000). The customer tries to express his taste and his style by buying and possessing luxury brands. As mentioned before the individual consumer purchases luxury brands with a brand image similar to his individual image (Kapferer \& Valette-Florence, 2016a).

During the process of self-realization brands underline the current personality traits of the individual and they enable customers to achieve desired characteristics which culminates in the achievement of the ideal self (Burmann, Riley, Halaszovich, \& Schade, 2017). Especially luxury brands represent associations and values taken into consideration with reference to their aspired self-concept (Zhu et al., 2019). Consumers use the symbolic value of luxury brands to categorize themselves in society and to demonstrate their sense of ideal (J. C. Kim, Park, \& Dubois, 2018). 
A luxury brand's long brand heritage amplifies the symbolic significance of a brand. Luxury brands possess a strong brand personality (Boccardi, Ciappei, Zollo, \& Laudano, 2016). Customers have the ability to transfer the brand image to their own image and have the possibility to achieve their aspired values due to the symbolic value of luxury brands (Shimul et al., 2019). The fact that individuals buy products not only for utilitarian reasons but also because of their symbolic meaning explains that consumers buy products due to cognitive and even affective unconscious reasons (Seo \& BuchananOliver, 2019). Society has developed to a hedonistic society. The consumers' desire will be satisfied by the hedonistic functions of brands (Roncha \& Montecchi, 2017). The consumption of brands arouses feelings of pleasure, fun, happiness, good health and the feeling of aesthetic elegancy (Stępień, 2018). The level on which luxury brands have the ability to satisfy the individual's need to indulge himself, to reward himself or to grant something special to himself is much higher than the level of ordinary brands (Conejo \& Cunningham, 2017). Most of the luxury brands are able to offer their consumers a very emotional experience and a special indulgence due to their impression (van der Westhuizen, 2018). Brands which communicate precisely defined values over long periods of time are qualified to express the current or ideal self (Becker, Lee, \& Nobre, 2018).

\section{References}

Aaker, J. L. (1999). The malleable self: The role of self-expression in persuasion. Journal of marketing research, 36(1), 45-57. https://doi.org/10.1177/002224379903600104

Adam, H., Obodaru, O., Lu, J. G., Maddux, W. W., \& Galinsky, A. D. (2018). The shortest path to oneself leads around the world: Living abroad increases self-concept clarity. Organizational Behavior and Human Decision Processes, 145, 16-29. https://doi.org/10.1016/j.obhdp.2018.01.002

Astakhova, M., Swimberghe, K. R., \& Wooldridge, B. R. (2017). Actual and ideal-self congruence and dual brand passion. Journal of Consumer Marketing, 34(7), 664-672. https://doi.org/10.1108/JCM-10-2016-1985

Atwal, G., \& Williams, A. (2009). Luxury brand marketing-The experience is everything! Journal of Brand Management, 16, 338-346. https://doi.org/10.1007/978-3-319-51127-6_3

Barnett, M. D., \& Womack, P. M. (2015). Fearing, not loving, the reflection: Narcissism, self-esteem, and selfdiscrepancy theory. Personality and Individual Differences, 74, 280-284. https://doi.org/10.1016/j.paid.2014.10.032

Becker, K., Lee, J. W., \& Nobre, H. M. (2018). The Concept of Luxury Brands and the Relationship between Consumer and Luxury Brands. Kip Becker, Jung Wan Lee, Helena M. Nobre/Journal of Asian Finance, Economics and Business, 5(3), 51-63. https://doi.org/10.13106/jafeb.2018.vol5.no3.51

Benthaus, J., Risius, M., \& Beck, R. (2016). Social media management strategies for organizational impression management and their effect on public perception. The Journal of Strategic Information Systems, 25(2), 127-139. https://doi.org/10.1016/j.jsis.2015.12.001

Berkman, E. T., Livingston, J. L., \& Kahn, L. E. (2017). Finding the "self" in self-regulation: The identity-value model. Psychological Inquiry, 28(2-3), 77-98. https://doi.org/10.1080/1047840X.2017.1323463

Bloch, P. H., \& Richins, M. L. (1992). You look "mahvelous": The pursuit of beauty and the marketing concept. Psychology \& Marketing, 9(1), 3-15. https://doi.org/10.1002/mar.4220090103

Boccardi, A., Ciappei, C., Zollo, L., \& Laudano, M. C. (2016). The role of heritage and authenticity in the value creation of fashion brand. International Business Research, 9(7), 135-143. https://doi.org/10.5539/ibr.v9n7p135

Brenner, P. S., Serpe, R. T., \& Stryker, S. (2018). Role-specific self-efficacy as precedent and product of the identity model. Sociological Perspectives, 61(1), 57-80. https://doi.org/10.1177/0731121417697306

Burmann, C., Riley, N.-M., Halaszovich, T., \& Schade, M. (2017). The Foundations of Identity-Based Brand Management. In Identity-Based Brand Management (pp. 1-16): Springer. 
Can, Y., \& Erdil, O. (2018). Determining Antecedent of Re-Purchase Intention: The Role of Perceived Value and Consumer's Interest Factor. International Business Research, 11(4), 17-31. https://doi.org/10.5539/ibr.v11n4p17

Carter, M. J., \& Fuller, C. (2016). Symbols, meaning, and action: The past, present, and future of symbolic interactionism. Current Sociology, 64(6), 931-961. https://doi.org/10.1177/0011392116638396

Cast, A. D., \& Stets, J. E. (2016). The Self. In Handbook of Contemporary Sociological Theory (pp. 343-365): Springer.

Chang, X., Wang, H., Guo, D., \& Cui, Z. (2018). The Philosophical Basis of Social Turning of Embodied Cognition From the Perspective of Symbolic Interactionism. Philosophy Study, 8(7), 309-314. https://doi.org/10.17265/2159-5313/2018.07.002

Chen, S. Y., Urminsky, O., \& Bartels, D. M. (2016). Beliefs about the causal structure of the self-concept determine which changes disrupt personal identity. Psychological Science, 27(10), 1398-1406. https://doi.org/10.1177/0956797616656800

Conejo, F. J., \& Cunningham, L. F. (2016). Current issues in luxury brand research. Journal of International Marketing Strategy, 4(1), 66-77.

Conejo, F. J., \& Cunningham, L. F. (2017). On Luxury Brand Dimensionality. Journal of International Marketing Strategy, 5(1), 49-63.

Constantine, G. R. (2017). The Biological Basis of Performativity of Identity-Linking Scientific Evidence to Social Theory. Journal of Ethnic and Cultural Studies, 4(2), 88-95.

Cristini, H., Kauppinen-Räisänen, H., Barthod-Prothade, M., \& Woodside, A. (2017). Toward a general theory of luxury: Advancing from workbench definitions and theoretical transformations. Journal of Business Research, 70, 101-107. https://doi.org/10.1016/j.jbusres.2016.07.001

Dimofte, C. V., Goodstein, R. C., \& Brumbaugh, A. M. (2015). A social identity perspective on aspirational advertising: Implicit threats to collective self-esteem and strategies to overcome them. Journal of Consumer Psychology, 25(3), 416-430. https://doi.org/10.1016/j.jcps.2014.12.001

Dion, D., \& Borraz, S. (2015). Managing heritage brands: A study of the sacralization of heritage stores in the luxury industry. Journal of Retailing and Consumer Services, 22, 77-84. https://doi.org/10.1016/j.jretconser.2014.09.005

Dogan, V., Ozkara, B. Y., \& Dogan, M. (2018). Luxury consumption tendency: conceptualization, scale development and validation. Current Psychology, 1-19. https://doi.org/10.1007/s12144-018-9813-y

Ein-Gar, D. (2015). Committing under the shadow of tomorrow: Self-control and commitment to future virtuous behaviors. Journal of Consumer Psychology, 25(2), 268-285. https://doi.org/10.1016/j.jcps.2014.08.006

Fastoso, F., Bartikowski, B., \& Wang, S. (2018). The "little emperor" and the luxury brand: How overt and covert narcissism affect brand loyalty and proneness to buy counterfeits. Psychology \& Marketing, 35(7), 522-532. https://doi.org/10.1002/mar.21103

Feng, C., Yan, X., Huang, W., Han, S., \& Ma, Y. (2018). Neural representations of the multidimensional self in the cortical midline structures. Neurolmage, 183, 291-299. https://doi.org/10.1016/j.neuroimage.2018.08.018

Fielding, K. S., \& Hornsey, M. J. (2016). A social identity analysis of climate change and environmental attitudes and behaviors: insights and opportunities. Frontiers in psychology, 7(121), 1-12. https://doi.org/10.3389/fpsyg.2016.00121

Fischer, L., \& Wiswede, G. (2009). Grundlagen der Sozialpsychologie, 3., völlig neu bearb. Aufl., München.

Fox, A. K., Bacile, T. J., Nakhata, C., \& Weible, A. (2018). Selfie-marketing: exploring narcissism and self-concept in visual user-generated content on social media. Journal of Consumer Marketing, 35(1), 11-21. https://doi.org/10.1108/JCM-03-2016-1752

Gardner, W. L., \& Garr-Schultz, A. (2017). Understanding our groups, understanding ourselves: The importance of collective identity clarity and collective coherence to the self. In Self-Concept Clarity (pp. 125-143): Springer.

Gecas, V. (1982). The self-concept. Annual review of sociology, 8(1), 1-33. https://doi.org/10.1146/annurev.so.08.080182.000245 
Gecas, V., \& Schwalbe, M. L. (1983). Beyond the looking-glass self: Social structure and efficacy-based self-esteem. Social psychology quarterly, 77-88. https://doi.org/10.2307/3033844

Geukes, K., van Zalk, M., \& Back, M. D. (2018). Understanding personality development: An integrative state process model. International Journal of Behavioral Development, 42(1), 43-51. https://doi.org/10.1177/0165025416677847

Grouchy, P., D’Eleuterio, G. M., Christiansen, M. H., \& Lipson, H. (2016). On the evolutionary origin of symbolic communication. Scientific reports, 6(1), 1-9. https://doi.org/10.1038/srep34615

Grubb, E. L., \& Grathwohl, H. L. (1967). Consumer self-concept, symbolism and market behavior: A theoretical approach. Journal of Marketing, 31(4), 22-27. https://doi.org/10.1177/002224296703100405

Harrison, C. K., Bukstein, S., Sutton, W. A., McArdle, D. H., Dickens, J., \& Lawrence, S. M. (2018). A Qualitative Investigation of Academic and Athletic Brand Representations: Applying Lovemarks Theory to Cultural Symbol. Journal of Higher Education Athletics \& Innovation(5), 15-36. https://doi.org/10.15763/issn.23765267.2018.1.5.15-36

Hart, W., Adams, J., Burton, K. A., \& Tortoriello, G. K. (2017). Narcissism and self-presentation: Profiling grandiose and vulnerable Narcissists' self-presentation tactic use. Personality and Individual Differences, 104, 48-57. https://doi.org/10.1016/j.paid.2016.06.062

Haslam, S. A., Cornelissen, J. P., \& Werner, M. D. (2017). Metatheories and metaphors of organizational identity: Integrating social constructionist, social identity, and social actor perspectives within a social interactionist model. International Journal of Management Reviews, 19(3), 318-336. https://doi.org/10.1111/ijmr.12150

Hogg, M., Cox, A., \& Keeling, K. (2000). The impact of self-monitoring on image congruence and product/brand evaluation. European Journal of Marketing, 34(5/6), 641-666. https://doi.org/10.1108/03090560010321974

Hogg, M. A., Abrams, D., \& Brewer, M. B. (2017). Social identity: The role of self in group processes and intergroup relations. Group Processes \& Intergroup Relations, 20(5), 570-581. https://doi.org/10.1177/1368430217690909

Išoraitè, M. (2018). Brand Image Theoretical Aspects. Integrated Journal of Business and Economics, 2(1), 116122.

James, W., Burkhardt, F., Bowers, F., \& Skrupskelis, I. K. (1890). The principles of psychology (Vol. 1): Macmillan London.

Janssen, C., Vanhamme, J., \& Leblanc, S. (2017). Should luxury brands say it out loud? Brand conspicuousness and consumer perceptions of responsible luxury. Journal of Business Research, 77, 167-174. https://doi.org/10.1016/j.jbusres.2016.12.009

Japutra, A., Ekinci, Y., Simkin, L., \& Nguyen, B. (2018). The role of ideal self-congruence and brand attachment in consumers' negative behaviour: compulsive buying and external trash-talking. European Journal of Marketing, 52(3/4), 683-701. https://doi.org/10.1108/EJM-06-2016-0318

Jetten, J., Haslam, S. A., Cruwys, T., Greenaway, K. H., Haslam, C., \& Steffens, N. K. (2017). Advancing the social identity approach to health and well-being: Progressing the social cure research agenda. European journal of social psychology, 47(7), 789-802. https://doi.org/10.1002/ejsp.2333

Jia, F., Soucie, K., Alisat, S., Curtin, D., \& Pratt, M. (2017). Are environmental issues moral issues? Moral identity in relation to protecting the natural world. Journal of Environmental Psychology, 52, 104-113. https://doi.org/10.1016/j.jenvp.2017.06.004

Kapferer, J.-N., \& Laurent, G. (2016). Where do consumers think luxury begins? A study of perceived minimum price for 21 luxury goods in 7 countries. Journal of Business Research, 69(1), 332-340. https://doi.org/10.1016/j.jbusres.2015.08.005

Kapferer, J.-N., \& Michaut, A. (2015). Luxury and sustainability: a common future? The match depends on how consumers define luxury. Luxury Research Journal, 1(1), 3-17. https://doi.org/10.1504/LRJ.2015.069828

Kapferer, J.-N., \& Valette-Florence, P. (2016a). Beyond rarity: the paths of luxury desire. How luxury brands grow yet remain desirable. Journal of Product \& Brand Management, 25(2), 120-133. https://doi.org/10.1108/JPBM09-2015-0988 
Kapferer, J.-N., \& Valette-Florence, P. (2016b). Is luxury sufficient to create brand desirability? A cross-cultural analysis of the relationship between luxury and dreams. Luxury Research Journal, 1(2), 110-127. https://doi.org/10.1504/LRJ.2016.078129

Kassim, N. M., \& Zain, M. M. (2016). Quality of lifestyle and luxury purchase inclinations from the perspectives of affluent Muslim consumers. Journal of Islamic Marketing, 7(1), 95-119. https://doi.org/10.1108/JIMA-08-20140052

Kauppinen-Räisänen, H., Björk, P., Lönnström, A., \& Jauffret, M.-N. (2018). How consumers' need for uniqueness, self-monitoring, and social identity affect their choices when luxury brands visually shout versus whisper. Journal of Business Research, 84, 72-81. https://doi.org/10.1016/j.jbusres.2017.11.012

Kenny, M., \& Fourie, R. (2015). Contrasting classic, Straussian, and constructivist grounded theory: methodological and philosophical conflicts. The Qualitative Report, 20(8), 1270-1289.

Kim, J., \& Joung, H.-M. (2016). Psychological underpinnings of luxury brand goods repurchase intentions: Brandself congruity, emotional attachment, and perceived level of investment made. Journal of Global Scholars of Marketing Science, 26(3), 284-299. https://doi.org/10.1080/21639159.2016.1174542

Kim, J. C., Park, B., \& Dubois, D. (2018). How consumers' political ideology and status-maintenance goals interact to shape their desire for luxury goods. Journal of Marketing, 82(6), $132-149$. https://doi.org/10.1177/0022242918799699

Ko, E., Costello, J. P., \& Taylor, C. R. (2017). What is a luxury brand? A new definition and review of the literature. Journal of Business Research, 405-413. https://doi.org/10.1016/j.jbusres.2017.08.023

Krishnamohan, V., \& Suma, M. V. P. (2018). Symbolic Consumption in the Indian Markets: Analysis of Determining Factors. Archives of Business Research, 6(4), 143-154. https://doi.org/10.14738/abr.64.4474

Lee, E., M. Edwards, S., Youn, S., \& Yun, T. (2018). Understanding the moderating effect of motivational values on young consumers' responses to luxury brands: A cross-cultural study of South Korea and the USA. Journal of Marketing Communications, 24(2), 103-124. https://doi.org/10.1080/13527266.2014.975830

Lee, J. E., Hur, S., \& Watkins, B. (2018). Visual communication of luxury fashion brands on social media: effects of visual complexity and brand familiarity. Journal of Brand Management, 25(5), 449-462. https://doi.org/10.1057/s41262-018-0092-6

Lee, S., Baumgartner, H., \& Winterich, K. P. (2018). Did they earn it? Observing unearned luxury consumption decreases brand attitude when observers value fairness. Journal of Consumer Psychology, 28(3), 412-436. https://doi.org/10.1002/jcpy.1028

Loureiro, S. M. C., Maximiano, M., \& Panchapakesan, P. (2018). Engaging fashion consumers in social media: the case of luxury brands. International Journal of Fashion Design, Technology and Education, 11(3), 310-321. https://doi.org/10.1080/17543266.2018.1431810

Mahadevan, N., Gregg, A., Sedikides, C., \& Waal-Andrews, D. (2016). Winners, losers, insiders, and outsiders: Comparing hierometer and sociometer theories of self-regard. Frontiers in psychology, 7, 1-19. https://doi.org/10.3389/fpsyg.2016.00334

Malhotra, N. K. (1988). Self concept and product choice: An integrated perspective. Journal of Economic Psychology, 9(1), 1-28. https://doi.org/10.1016/0167-4870(88)90029-3

Mandel, N., Rucker, D. D., Levav, J., \& Galinsky, A. D. (2017). The compensatory consumer behavior model: How self-discrepancies drive consumer behavior. Journal of Consumer Psychology, 27(1), 133-146. https://doi.org/10.1016/j.jcps.2016.05.003

Markus, H., \& Wurf, E. (1987). The dynamic self-concept: A social psychological perspective. Annual review of psychology, 38(1), 299-337. https://doi.org/10.1146/annurev.ps.38.020187.001503

Marsh, H., Pekrun, R., Parker, P., Murayama, K., Guo, J., Dicke, T., \& Arens, A. (2019). The Murky Distinction Between Self-Concept and Self-Efficacy: Beware of Lurking Jingle-Jangle Fallacies. Journal of Educational Psychology, 111(2), 331-353. https://doi.org/10.1037/edu0000281

Martiny, S. E., \& Rubin, M. (2016). Towards a clearer understanding of social identity theory's self-esteem hypothesis. In Understanding Peace and Conflict Through Social Identity Theory (pp. 19-32): Springer. 
McGowan, M., Shiu, E., \& Hassan, L. M. (2017). The influence of social identity on value perceptions and intention. Journal of consumer behaviour, 16(3), 242-253. https://doi.org/10.1002/cb.1627

Mead, G. H. (1913). The social self. The Journal of Philosophy, Psychology and Scientific Methods, 10(14), 374380. https://doi.org/10.2307/2012910

Miller, K. W., \& Mills, M. K. (2012). Contributing clarity by examining brand luxury in the fashion market. Journal of Business Research, 65(10), 1471-1479. https://doi.org/10.1016/j.jbusres.2011.10.013

Mishra, S. (2016). Self Concept-A Person's Concept of Self-Influence. International Journal of Recent Research Aspects, Special Issue: Conscientious and Unimpeachable Technologies, 1, 8-13.

Mittal, B. (2015). Self-concept clarity: Exploring its role in consumer behavior. Journal of Economic Psychology, 46, 98-110. https://doi.org/10.1016/j.joep.2014.11.003

Mor Barak, M. E., Lizano, E. L., Kim, A., Duan, L., Rhee, M.-K., Hsiao, H.-Y., \& Brimhall, K. C. (2016). The promise of diversity management for climate of inclusion: A state-of-the-art review and meta-analysis. Human Service Organizations: Management, Leadership \& Governance, 40(4), 305-333. https://doi.org/10.1080/23303131.2016.1138915

Mõttus, R. (2016). Towards more rigorous personality trait-outcome research. European Journal of Personality, 30(4), 292-303. https://doi.org/10.1002/per.2041

Moulard, J. G., Raggio, R. D., \& Folse, J. A. G. (2016). Brand authenticity: Testing the antecedents and outcomes of brand management's passion for its products. Psychology \& Marketing, 33(6), 421-436. https://doi.org/10.1002/mar.20888

Obschonka, M., Silbereisen, R. K., Cantner, U., \& Goethner, M. (2015). Entrepreneurial self-identity: predictors and effects within the theory of planned behavior framework. Journal of Business and Psychology, 30(4), 773794. https://doi.org/10.1007/s10869-014-9385-2

Pappas, I. O., Kourouthanassis, P. E., Giannakos, M. N., \& Chrissikopoulos, V. (2017). Sense and sensibility in personalized e-commerce: How emotions rebalance the purchase intentions of persuaded customers. Psychology \& Marketing, 972-986. https://doi.org/10.1002/mar.21036

Pilarska, A. (2018). Big-Five personality and aspects of the self-concept: Variable-and person-centered approaches. Personality and Individual Differences, 127, 107-113. https://doi.org/10.1016/j.paid.2018.01.049

Porankiewicz-Żukowska, A. (2017). The biological foundations of identity in the works of Antonio Damasio. The sociological implications. Studies in Logic, Grammar and Rhetoric, 50(1), 227-238. https://doi.org/10.1515/slgr2017-0026

Richman, S. B., Slotter, E. B., Gardner, W. L., \& DeWall, C. N. (2015). Reaching out by changing what's within: Social exclusion increases self-concept malleability. Journal of Experimental Social Psychology, 57, 64-77. https://doi.org/10.1016/j.jesp.2014.11.008

Roe, D., \& Bruwer, J. (2017). Self-concept, product involvement and consumption occasions: Exploring fine wine consumer behaviour. British Food Journal, 119(6), 1362-1377. https://doi.org/10.1108/BFJ-10-2016-0476

Roncha, A., \& Montecchi, M. (2017). The Underpinning Strategies Leading to High Value Perception of Luxury Fashion Brands. IUP Journal of Brand Management, 14(3), 7-21.

Ross, I. (1971). Self-concept and brand preference. The Journal of Business, 44(1), 38-50. https://doi.org/10.1086/208590

Roux, E., Tafani, E., \& Vigneron, F. (2017). Values associated with luxury brand consumption and the role of gender. Journal of Business Research, 100(71), 102-113. https://doi.org/10.1016/j.jbusres.2016.10.012

Roy, S. S. A. S. S. (2016). Validating a scale to measure consumer's luxury brand aspiration. Journal of Product \& Brand Management, 25(5), 465-478. https://doi.org/10.1108/JPBM-06-2014-0647

Sampthirao, P. (2016). Self-concept and interpersonal communication. The International Journal of Indian Psychology, 3(3), 177-189.

Schwartz, S. J., Meca, A., \& Petrova, M. (2017). Who am I and why does it matter? Linking personal identity and self-concept clarity. In Self-concept clarity (pp. 145-164): Springer. 
Sedikides, C., Gaertner, L., \& Cai, H. (2015). On the panculturality of self-enhancement and self-protection motivation: The case for the universality of self-esteem. In Advances in motivation science (Vol. 2, pp. 185-241): Elsevier.

Semaan, R. W., Ashill, N., Williams, P., \& Dhabi, A. (2019). Sophisticated, Iconic and Magical: A Qualitative Analysis of Brand Charisma. Journal of Retailing and Consumer Services, 49, 102-113. https://doi.org/10.1016/j.jretconser.2019.03.011

Seo, Y., \& Buchanan-Oliver, M. (2019). Constructing a typology of luxury brand consumption practices. Journal of Business Research, 99, 414-421. https://doi.org/10.1016/j.jbusres.2017.09.019

Setyawan, A. A., \& Kussudiyarsana, I. (2015). Brand trust and brand loyalty, an empirical study in Indonesia consumers. British Journal of Marketing Studies, 4(3), 37-47.

Sharda, N., \& Bhat, A. K. (2018). Austerity to materialism and brand consciousness: luxury consumption in India. Journal of Fashion Marketing and Management: An International Journal, 22(2), 223-239. https://doi.org/10.1108/JFMM-03-2017-0025

Shimul, A. S., Phau, I., \& Lwin, M. (2019). Conceptualising luxury brand attachment: scale development and validation. Journal of Brand Management, 26(6), 675-690. https://doi.org/10.1057/s41262-019-00158-6

Shin, H., Eastman, J. K., \& Mothersbaugh, D. (2017). The effect of a limited-edition offer following brand dilution on consumer attitudes toward a luxury brand. Journal of Retailing and Consumer Services, 38, 59-70. https://doi.org/10.1016/j.jretconser.2017.05.009

Showers, C. J., Ditzfeld, C. P., \& Zeigler-Hill, V. (2015). Self-concept structure and the quality of self-knowledge. Journal of personality, 83(5), 535-551. https://doi.org/10.1111/jopy.12130

Sirgy, M. J. (1982). Self-concept in consumer behavior: A critical review. Journal of consumer research, 9(3), 287300. https://doi.org/10.1086/208924

Solomon, M. R. (1983). The role of products as social stimuli: A symbolic interactionism perspective. Journal of consumer research, 10(3), 319-329. https://doi.org/10.1086/208971

Steffens, N. K., Schuh, S. C., Haslam, S. A., Perez, A., \& van Dick, R. (2015). 'Of the group'and 'for the group': How followership is shaped by leaders' prototypicality and group identification. European journal of social psychology, 45(2), 180-190. https://doi.org/10.1002/ejsp.2088

Stępień, B. (2018). Snobbish bandwagoners: Ambiguity of luxury goods' perception. Journal of Management and Business Administration. Central Europe, 26(1), 79-99. https://doi.org/10.7206/jmba.ce.2450-7814.220

Suchańska, A., \& Worach, A. (2017). Self-complexity and the sense of identity. Roczniki Psychologiczne/Annals of Psychology, 16(2), 217-233.

Sung, B., \& Phau, I. (2019). When pride meets envy: Is social superiority portrayal in luxury advertising perceived as prestige or arrogance? Psychology \& Marketing, 36(2), 113-119. https://doi.org/10.1002/mar.21162

Sutton, A. (2018). Distinguishing between authenticity and personality consistency in predicting well-being: A mixed method approach. Revue Europeenne de Psychologie Appliquee, 68(3), 117-130. https://doi.org/10.1016/j.erap.2018.06.001

Tak, P., Pareek, A., \& Rishi, B. (2017). Social Comparison of Luxury Fashion Brands: Impact of Ostentation and Media Habits. The IUP Journal of Marketing Management, 16(1), 29-46.

Tooray, J., \& Oodith, D. (2017). The Influence of Actual and Ideal Self-Congruity on Consumers' Purchase Intentions. Journal of Economics and Behavioral Studies, 9(4), 107-121. https://doi.org/10.22610/jebs.v9i4(J).1826

Tran, L. T., \& Pham, L. (2016). International students in transnational mobility: Intercultural connectedness with domestic and international peers, institutions and the wider community. Compare: A Journal of Comparative and International Education, 46(4), 560-581. https://doi.org/10.1080/03057925.2015.1057479

Trepte, S., \& Loy, L. S. (2017). Social Identity Theory and Self-Categorization Theory. The international encyclopedia of media effects, 1-13. https://doi.org/10.1002/9781118783764.wbieme0088 
Tsai, Y.-C., Chang, H.-C., \& Ho, K.-C. (2015). A Study of the Relationship among Brand Experiences, Self-Concept Congruence, Customer Satisfaction, and Brand Preference. Contemporary Management Research, 11(2), 97-116. https://doi.org/10.7903/cmr.12970

Turner-Zwinkels, F. M., Postmes, T., \& van Zomeren, M. (2015). Achieving Harmony among Different Social Identities within the Self-Concept: The Consequences of Internalising a Group-Based Philosophy of Life. PLOS ONE, 10(11), 1-31. https://doi.org/10.1371/journal.pone.0137879

Uggla, H. (2017). Post-Structural Luxury Brand Strategy: Implicit Luxury Brands. IUP Journal of Brand Management, 14(3), 22-29.

Uher, J. (2017). Basic definitions in personality psychology: Challenges for conceptual integrations. European Journal of Personality, 31(5), 572-573.

Ümmet, D. (2015). Self esteem among college students: a study of satisfaction of basic psychological needs and some variables. Procedia-Social and Behavioral Sciences, 174(2015), 1623-1629. https://doi.org/10.1016/j.sbspro.2015.01.813

van der Westhuizen, L.-M. (2018). Brand loyalty: exploring self-brand connection and brand experience. Journal of Product \& Brand Management, 27(2), 172-184. https://doi.org/10.1108/JPBM-07-2016-1281

Vernuccio, M., Pagani, M., Barbarossa, C., \& Pastore, A. (2015). Antecedents of brand love in online networkbased communities. A social identity perspective. Journal of Product \& Brand Management, 24(7), 706-719. https://doi.org/10.1108/JPBM-12-2014-0772

Whelpley, C. E., \& McDaniel, M. A. (2016). Self-esteem and counterproductive work behaviors: a systematic review. Journal of Managerial Psychology, 31(4), 850-863. https://doi.org/10.1108/JMP-01-2014-0008

Wry, T., \& York, J. G. (2017). An identity-based approach to social enterprise. Academy of Management Review, 42(3), 437-460. https://doi.org/10.5465/amr.2013.0506

Zeugner-Roth, K. P., Žabkar, V., \& Diamantopoulos, A. (2015). Consumer ethnocentrism, national identity, and consumer cosmopolitanism as drivers of consumer behavior: A social identity theory perspective. Journal of International Marketing, 23(2), 25-54. https://doi.org/10.1509/jim.14.0038

Zhu, X., Teng, L., Foti, L., \& Yuan, Y. (2019). Using self-congruence theory to explain the interaction effects of brand type and celebrity type on consumer attitude formation. Journal of Business Research, 103, 301-309. https://doi.org/10.1016/j.jbusres.2019.01.055 